NBER WORKING PAPER SERIES

\title{
ON THE INDUSTRY CONCENTRATION OF ACTIVELY MANAGED EQUITY MUTUAL FUNDS
}

\author{
Marcin Kacperczyk \\ Clemens Sialm \\ Lu Zheng \\ Working Paper 10770 \\ http://www.nber.org/papers/w10770 \\ NATIONAL BUREAU OF ECONOMIC RESEARCH
1050 Massachusetts Avenue
Cambridge, MA 02138
September 2004
}

Kacperczyk is from the Sauder School of Business at University of British Columbia. Sialm and Zheng are from the Michigan Business School, Ann Arbor. We thank Sreedhar Bharath, Sugato Bhattacharyya, Fang Cai, Joel Dickson, William Goetzmann, Rick Green, Gautam Kaul, Lutz Kilian, Zbigniew Kominek, Francine Lafontaine, Luboš Pástor, Tyler Shumway, Laura Starks, Steve Todd, Zhi Wang, Russ Wermers, Toni Whited, and especially an anonymous referee. We also benefited from helpful comments by seminar participants at the 2002 CIRANO seminar in Montreal, the 2003 European Financial Management Association Meeting in Helsinki, the 2003 Summer Meeting of the Econometric Society, the 2004 European Finance Association Meeting in Maastricht, Michigan State University, the University of Colorado at Boulder, the University of Florida, the University of Michigan, and the University of St. Gallen. We are grateful to Paul Michaud for his support with the CDA/Spectrum database. We thank the authors of DGTW (1997) for providing us with the characteristic-adjusted stock returns reported in their paper. We acknowledge the financial support from Mitsui Life Center in acquiring the CDA/Spectrum data. The views expressed herein are those of the author(s) and not necessarily those of the National Bureau of Economic Research.

(C2004 by Marcin Kacperczyk, Clemens Sialm, and Lu Zheng. All rights reserved. Short sections of text, not to exceed two paragraphs, may be quoted without explicit permission provided that full credit, including () notice, is given to the source. 
On the Industry Concentration of Actively Managed Equity Mutual Funds

Marcin Kacperczyk, Clemens Sialm, and Lu Zheng

NBER Working Paper No. 10770

September 2004

JEL No. G2

\begin{abstract}
Mutual fund managers may decide to deviate from a well-diversified portfolio and concentrate their holdings in industries where they have informational advantages. In this paper, we study the relation between the industry concentration and the performance of actively managed U.S. mutual funds from 1984 to 1999 . Our results indicate that, on average, more concentrated funds perform better after controlling for risk and style differences using various performance measures. This finding suggests that investment ability is more evident among managers who hold portfolios concentrated in a few industries.

Marcin Kacperczyk

Sauder School of Business

University of British Columbia

2053 Main Mall

Vancouver, B.C. Canada V6T 1Z2

marcin.kacperczyk@sauder.ubc.ca

Clemens Sialm

University of Michigan Business School

701 Tappan Street

D3219

Ann Arbor, MI 48109-1234

and NBER

sialm@umich.edu

Lu Zheng

University of Michigan Business School

701 Tappan Street

Ann Arbor, MI 48109-1234

luzheng@umich.edu
\end{abstract}


Actively managed mutual funds are an important constituent of the financial sector. Despite the well-documented evidence that, on average, actively managed funds underperform passive benchmarks, mutual fund managers might still differ substantially in their investment abilities. ${ }^{1}$ In this paper, we examine whether some fund managers create value by concentrating their portfolios in industries where they have informational advantages.

Conventional wisdom suggests that investors should widely diversify their holdings across industries to reduce their portfolios' idiosyncratic risk. Fund managers, however, might want to hold concentrated portfolios if they believe some industries will outperform the overall market or if they have superior information to select profitable stocks in specific industries. Consistent with this hypothesis, we would expect funds with skilled managers to hold more concentrated portfolios. As a result, we should observe a positive relation between fund performance and industry concentration.

Mutual fund managers may also hold concentrated portfolios due to a potential conflict of interest between fund managers and investors. Several studies indicate that investors reward stellar performance with disproportionately high money inflows but do not penalize poor performance equivalently. ${ }^{2}$ This behavior results in a convex optionlike payoff profile for mutual funds. Consequently, some managers, especially those with

\footnotetext{
${ }^{1}$ For evidence on fund performance, see, for example, Jensen (1968); Grinblatt and Titman (1989); Elton, Gruber, Das, and Hlavka (1993); Hendricks, Patel, and Zeckhauser (1993); Malkiel (1995); Brown and Goetzmann (1995); Ferson and Schadt (1996); Gruber (1996); Daniel, Grinblatt, Titman, and Wermers (DGTW 1997); Baks, Metrick, and Wachter (2001); Kosowski, Timmermann, White, and Wermers (2001); Carhart, Carpenter, Lynch and Musto (2002); Cohen, Coval, and Pástor (2004); and Lynch, Wachter, and Boudry (2004).

${ }^{2}$ Numerous studies have called attention to the nonlinearity in the performance-flow relation, for example, Ippolito (1992), Gruber (1996), Chevalier and Ellison (1997), Goetzmann and Peles (1997), Sirri and
} 
lower investment abilities, may have an incentive to adopt volatile investment strategies to increase their chances of having extreme performance. Consistent with this hypothesis, funds pursuing such gaming strategies would hold more concentrated portfolios. In this case, we should not observe a positive relation between fund performance and industry concentration.

The literature analyzing the net returns of mutual funds documents that mutual funds, on average, under-perform passive benchmarks by a statistically and economically significant margin. However, several studies based on the gross returns of the portfolio holdings of mutual funds conclude that managers who follow active investment strategies have stock-picking abilities. For example, Grinblatt and Titman (1989, 1993); Grinblatt, Titman, and Wermers (1995); Daniel, Grinblatt, Titman, and Wermers (DGTW 1997); Wermers (2000); and Frank, Poterba, Shackelford, and Shoven (2004) find evidence that mutual fund managers outperform their benchmarks based on the returns of fund holdings.

Coval and Moskowitz $(1999,2001)$ show that mutual funds exhibit a strong preference for investing in locally headquartered firms where they appear to have informational advantages. Nanda, Wang, and Zheng (2004) provide evidence that fund families following more focused investment strategies across funds perform better, likely due to their informational advantages. To further investigate the informational advantages or investment abilities of mutual fund managers, we analyze in this paper whether some fund managers can create value by holding portfolios concentrated in specific industries.

Tufano (1998), Del Guercio and Tkac (2002), and Nanda, Wang, and Zheng (2004). 
Recent studies suggest the size of a fund affects its ability to outperform the benchmark. In a theoretical paper, Berk and Green (2004) explain many stylized facts related to fund performance using a model with rational agents. In their model, skilled active managers do not outperform passive benchmarks after deducting expenses because of a competitive market for capital provision combined with decreasing returns to scale in active management. In a related empirical study, Chen, Hong, Huang, and Kubik (2002) find that smaller funds tend to outperform larger funds due to diseconomies of scale. While the size of the fund negatively affects its performance, it is possible that a wide dispersion of holdings across many industries also may erode its performance. Our paper investigates whether such diseconomies of scope have important implications for asset management.

This paper evaluates a fund's performance conditioned upon its industry concentration. The rationale for selecting industry concentration as the conditioning variable is that skilled fund managers may exhibit superior performance by holding more concentrated portfolios to exploit their informational advantages. To date, there has been no research on whether portfolio concentration is related to fund performance.

Using U.S. mutual fund data from 1984 to 1999 , we construct portfolios of funds with different industry concentration levels. We develop our measure, the Industry Concentration Index, to quantify the extent of portfolio concentration in ten broadly defined industries. This index is based on the difference between the industry weights of a mutual fund and the industry weights of the total market portfolio. Our analysis indicates that mutual funds differ substantially in their industry concentration and that 
concentrated funds tend to follow distinct investment styles. Managers of more concentrated funds overweigh growth and small-cap stocks, whereas managers of more diversified funds hold portfolios that closely resemble the total market portfolio.

We find that more concentrated funds perform better after adjusting for risk and style differences using the four-factor model of Carhart (1997). Mutual funds with above median industry concentration yield an average abnormal return of $1.58 \%$ per year before deducting expenses and $0.33 \%$ per year after deducting expenses, whereas mutual funds with below median industry concentration yield an average abnormal return of $0.36 \%$ before and $-0.77 \%$ after expenses. We confirm the relation between fund concentration and performance using panel regressions controlling for other fund characteristics. Using the conditional measures of Ferson and Schadt (1996), we establish that the superior performance of concentrated funds is not due to their greater responsiveness to macroeconomic conditions.

To investigate the causes of the abnormal performance of concentrated portfolios, we follow DGTW (1997) and measure the performance of mutual funds based on their portfolio holdings using characteristic-based benchmarks. The results indicate that the superior performance of concentrated mutual funds is primarily due to their stock selection ability. Furthermore, we find that concentrated funds are able to select better stocks even after controlling for the average industry performance.

We also examine the trades of mutual funds and find that the stocks purchased tend to significantly outperform the stocks sold. Moreover, we show that the return difference between the buys and the sells by mutual funds increases significantly with 
industry concentration. This finding indicates that concentrated mutual funds are more successful in selecting securities than diversified funds.

The remainder of the paper proceeds as follows. We describe the data in Section I. Sections II and III define the concentration and performance measures, respectively. Section IV documents the empirical results and reports several robustness tests. Section V concludes.

\section{Data}

The main data set has been created by merging the CRSP Survivorship Bias Free Mutual Fund Database with the CDA/Spectrum holdings database and the CRSP stock price data. The CRSP Mutual Fund Database includes information on fund returns, total net assets, different types of fees, investment objectives, and other fund characteristics. One major constraint imposed on researchers using CRSP is that it does not provide detailed information about fund holdings. We follow Wermers (2000) and merge the CRSP database with the stockholdings database published by CDA Investments Technologies. The CDA database provides stockholdings of virtually all U.S. mutual funds. The data are collected both from reports filed by mutual funds with the SEC and from voluntary reports generated by the funds. We link each reported stock holding to the CRSP stock database in order to find its price and industry classification code. The vast majority of funds have holdings of companies listed on the NYSE, NASDAQ, or AMEX stock exchanges. However, there also are funds for which we are not able to identify the price and the industry code of certain holdings. The missing data, however, constitute less 
than $1 \%$ of all holdings. The Appendix provides further details pertaining to the merging process.

Our final sample spans the period between January 1984 and December 1999. We eliminate balanced, bond, index, international, and sector funds, and focus our analysis on actively managed diversified equity funds. In addition, we include funds with multiple share classes only once. We also eliminate all observations where fewer than 11 stock holdings could be identified. Finally, we exclude all fund observations where the size of the fund in the previous quarter does not exceed $\$ 1$ million. With all the exclusions, our final sample includes 1,771 actively managed diversified equity funds. Panel A of Table I presents summary statistics of the data.

[Insert Table I around here]

\section{Industry Concentration Index}

We define our measure of industry concentration, the Industry Concentration Index, based on the fund holdings. Specifically, we assign each stock held by a mutual fund to one of ten industries. In the Appendix, we present the detailed composition of the industries. The Industry Concentration Index $(I C I)$ at time $t$ for a mutual fund is defined as the sum of the squared deviations of the value weights for each of the ten different

industries held by the mutual fund, $w_{j, t}$, relative to the industry weights of the total stock market, $\bar{w}_{j, t} \cdot$ 


$$
I C I_{t}=\sum_{j=1}^{10}\left(w_{j, t}-\bar{w}_{j, t}\right)^{2} .
$$

The Industry Concentration Index measures how much a mutual fund portfolio deviates from the market portfolio. This index is equal to zero if a mutual fund has exactly the same industry composition as the market portfolio, and increases as a mutual fund becomes more concentrated in a few industries.

The Industry Concentration Index is related to the Herfindahl Index, which is commonly used in Industrial Organization to measure the concentration of companies in an industry. ${ }^{3}$ The Industry Concentration Index can be thought of as a market-adjusted Herfindahl Index. In our sample, it has a correlation coefficient of 0.93 with the Herfindahl Index. We choose the Industry Concentration Index for two reasons. First, the industry weights of the total market vary over time. The Industry Concentration Index takes this variation into account by adjusting for the time-varying industry weights in the market portfolio. Second, a mutual fund can have a lower Herfindahl Index than the entire market portfolio if it is more equally invested in the different industries. The Industry Concentration Index is not subject to this problem, because the market portfolio has the lowest possible index value of zero.

Panel A of Table I documents summary statistics for the Industry Concentration Index and other fund characteristics. The average actively managed mutual fund has an Industry Concentration Index of 5.98\%. The Industry Concentration Index ranges 
between 0.01 and $83.42 \%$, which demonstrates a significant cross-sectional variation of mutual funds with respect to their concentration level. Concentrated funds may differ substantially from diversified funds in numerous characteristics such as size, age, managerial fees, loads, and turnover. In Panel B of Table I, we examine the correlation between the Industry Concentration Index and fund characteristics. In general, we observe statistically significant correlations between the different characteristics. On average, concentrated funds have higher turnover and higher expenses than diversified funds. On the other hand, concentrated funds are younger and have a lower value of assets under management.

\section{Performance Measures}

To examine the relation between industry concentration and fund performance, we use both factor-based and holding-based performance measures. In this section, we describe the different measures we use to evaluate fund performance.

\section{A. Carhart Four-Factor Measure}

One of our measures is the Carhart (1997) four-factor model, which controls for risk and style factors. It is especially important to adjust for momentum in stock returns (Jegadeesh and Titman, 1993) of our industry concentration portfolios, as momentum is

\footnotetext{
${ }^{3}$ The Herfindahl Index is defined as $H_{t}=\sum_{i=1}^{N}\left(w_{i, t}\right)^{2}$. Using the Herfindahl Index instead of the Industry Concentration Index does not change the qualitative aspects of our results.
} 
stronger at an industry level (Moskowitz and Grinblatt, 1999). ${ }^{4}$ We estimate the following regression:

$R_{i, t}-R_{F, t}=\alpha_{i}+\beta_{i, M}\left(R_{M, t}-R_{F, t}\right)+\beta_{i, S M B} S M B_{t}+\beta_{i, H M L} H M L_{t}+\beta_{i, M O M} M O M_{t}+e_{i, t}$,

where the dependent variable is the quarterly return on portfolio $i$ in quarter $t$ minus the risk-free rate, and the independent variables are given by the returns of the four zeroinvestment factor portfolios. The expression $R_{M t}-R_{F t}$ denotes the excess return of the market portfolio over the risk-free rate $;^{5} S M B$ is the return difference between small and large capitalization stocks; $H M L$ is the return difference between high and low book-tomarket stocks; and $M O M$ is the return difference between stocks with high and low past returns. ${ }^{6}$ The intercept of the model, $\alpha_{i}$, is the Carhart measure of abnormal performance.

To account for possible differences in idiosyncratic risk exposure, we also compute the appraisal ratio of Treynor and Black (1973), defined as the ratio of the intercept from the regression equation (2) and the standard deviation of the residuals from the same regression.

\footnotetext{
${ }^{4}$ Carhart (1997) indicates that performance persistence mainly can be explained by including a momentum factor. Zheng (1999) suggests that the "smart-money" effect is closely related to momentum in stock returns. Nevertheless, our findings remain similar when we use the Fama and French (1993) three-factor model.

${ }^{5}$ The market return is calculated as the value-weighted return on all NYSE, AMEX, and NASDAQ stocks using the CRSP database. The monthly return of the one-month Treasury bill rate is obtained from Ibbotson Associates.

${ }^{6}$ The size, the value, and the momentum factor returns were taken from Kenneth French's Web site http://mba.tuck.dartmouth.edu/pages/faculty/ken.french/Data_Library.
} 


\section{B. Ferson-Schadt Conditional Measure}

Ferson and Schadt (1996) argue that the traditional unconditional measures of abnormal performance might be unreliable, because common variation in risk levels and risk premia will be confounded with average performance. They argue that a managed portfolio strategy that can be replicated using readily available public information should not be judged as having superior performance. They advocate a model based on conditional performance, which uses predetermined instruments to capture the timevarying factor loadings. Our specification of the conditional model follows Wermers (2003) and includes interaction terms between the excess market returns and various macro-economic variables:

$$
\begin{aligned}
R_{i, \tau}-R_{F, t}= & \alpha_{i}+\beta_{i, M}\left(R_{M, \tau}-R_{F, t}\right)+\beta_{i, S M B} S M B_{t}+\beta_{i, H M L} H M L_{t}+\beta_{i, M O M} M O M_{t} \\
& +\sum^{4}{ }_{\mathrm{j}=1} \beta_{i, j}\left[z_{j, t-1}\left(R_{M, \tau}-R_{F, t}\right)\right]+e_{i, t},
\end{aligned}
$$

where $z_{j, t-1}$ is the demeaned value of the lagged macro-economic variable $j$. Consistent with the previous studies, we consider the following four macro-economic variables: the one-month Treasury bill yield, the dividend yield of the S\&P 500 Index, the Treasury yield spread (long- minus short-term bonds), and the quality spread in the corporate bond market (low- minus high-grade bonds). ${ }^{7}$ The intercept of the model, $\alpha_{i}$, is the conditional measure of performance.

\footnotetext{
${ }^{7}$ Ferson and Schadt (1996) also include an indicator variable for January. We exclude this indicator variable because our data are at a quarterly frequency and because the coefficient on the interaction term between the excess market return and an indicator variable for the first quarter is usually not statistically significantly different from 0 .
} 


\section{DGTW Measures}

To investigate the causes of the abnormal performance, we use an alternative set of measures based on the fund holdings rather than the time-series of fund returns. DGTW (1997) decompose the overall return of a fund into a "Characteristic Selectivity" measure $C S$, a "Characteristic Timing" measure $C T$, and an "Average Style" measure $A S$.

To form the benchmark portfolios, we follow DGTW (1997) and group the universe of common stocks listed on the NYSE, NASDAQ, and AMEX into quintiles along the dimensions of size (market value of equity), book-to-market ratio, and momentum (the return of a stock in the previous year). This sequential sorting results in 125 passive portfolios. We calculate the value-weighted returns on each benchmark portfolio. DGTW (1997) describe the computation of these benchmarks in more detail.

The variable $C S$ denotes a measure of stock selection ability and uses as a benchmark the return of a portfolio of stocks that is matched to each of the fund's stock holdings every quarter along the dimensions of size, book-to-market ratio, and momentum:

$$
C S_{t}=\sum_{j} w_{j, t-1}\left[R_{j, t}-B R_{t}(j, t-1)\right],
$$

where $R_{j, t}$ is the return on stock $j$ during period $t ; B R_{t}(j, t-k)$ is the return on a benchmark portfolio during period $t$ to which stock $j$ was allocated during period $t-k$ according to its size, value, and momentum characteristics; and $w_{j, t-k}$ is the relative weight of stock $j$ at the end of period $t-k$ in the mutual fund. 
The variable $C T$ denotes a measure of style timing ability, which examines whether fund managers can generate additional performance by exploiting time-varying expected returns of the size, book-to-market, or momentum benchmark portfolios:

$$
C T_{t}=\sum_{j}\left[w_{j, t-1} B R_{t}(j, t-1)-w_{j, t-5} B R_{t}(j, t-5)\right] .
$$

As in DGTW (1997), we use the $A S$ measure to capture the returns earned by a fund due to a fund's tendency to hold stocks with certain characteristics. The $A S$ measure is defined as:

$$
A S_{t}=\sum_{j}\left[w_{j, t-5} B R_{t}(j, t-5)\right]
$$

\section{Industry-Adjusted Measures}

To adjust a fund's performance for industry returns, we develop the industry stock selectivity measure, $I S$, and the industry timing measure, $I T$. The variable $I S$ measures a manager's ability to select superior stocks within industries, while IT is a measure of a manager's ability to select superior industries. The measures $I S$ and $I T$ are defined in two steps. In the first step, we compute the industry-adjusted performance using the returns of the 48 industries:

$$
\begin{gathered}
I S_{t}=\sum_{j} w_{j, t-1}\left[R_{j, t}-I R_{t}(j, t-1)\right] \\
I T_{t}=\sum_{j}\left[w_{j, t-1} I R_{t}(j, t-1)-w_{j, t-5} I R_{t}(j, t-5)\right],
\end{gathered}
$$


where $I R_{t}(j, t-k)$ is the return on an industry portfolio during period $t$, to which stock $j$ was allocated during period $t-k$. The variables $R$ and $w$ are the same as defined previously. In the second step, we regress the $I S$ and $I T$ measures on the Carhart fourfactor model to obtain industry-adjusted abnormal returns.

\section{E. Trade Portfolios}

Chen, Jagadeesh, and Wermers (2000) and Kothari and Warner (2001) suggest that examining trades can be a more powerful method to find value in active fund management than examining holdings. To analyze mutual fund trades, we compute for each fund the average quarterly returns of the stocks purchased and sold during the previous six months. The average returns of the buys and sells of a mutual fund during quarter $t$ are computed as follows:

$$
\begin{array}{r}
R_{t}^{\text {Buys }}=\frac{\sum_{w_{j, t-1}>\widetilde{w}_{j, t-3}}\left(w_{j, t-1}-\widetilde{w}_{j, t-3}\right) R_{j, t}}{\sum_{w_{j, t-1}>\widetilde{w}_{j, t-3}}\left(w_{j, t-1}-\widetilde{w}_{j, t-3}\right)} \\
R_{t}^{\text {Sells }}=\frac{\sum_{w_{j, t-1}<\widetilde{w}_{j, t-3}}\left(w_{j, t-1}-\widetilde{w}_{j, t-3}\right) R_{j, t}}{\sum_{w_{j, t-1}<\widetilde{w}_{j, t-3}}\left(w_{j, t-1}-\widetilde{w}_{j, t-3}\right)} .
\end{array}
$$

The weight of stock $j$ in a mutual fund at the end of the previous quarter is denoted by $w_{j, t-1}$ and the return of stock $j$ during quarter $t$ is denoted by $R_{j, t}$. We adjust 
for the weight changes that occur due to price changes in buy-and-hold portfolios. Thus, the lagged weight $\widetilde{w}_{j, t-3}$ is defined as follows:

$$
\widetilde{w}_{j, t-3}=\frac{w_{j, t-3}\left(1+R_{j, t-2}\right)\left(1+R_{j, t-1}\right)}{\sum_{j} w_{j, t-3}\left(1+R_{j, t-2}\right)\left(1+R_{j, t-1}\right)} .
$$

We also compute the return difference between stock purchases and liquidations:

$$
R_{t}^{\text {Buys-Sells }}=R_{t}^{\text {Buys }}-R_{t}^{\text {Sells }} .
$$

We use two measures of performance for the trades. The first measure is the raw return and the second measure is the stock selection ability measure CS from DGTW (1997). For the second measure, we replace the raw returns $R$ in equations (9), (10), and (12) with the style-adjusted returns $C S$.

\section{Empirical Evidence}

In this section, we present the empirical results. First, we investigate the relation between industry concentration and fund performance using both a portfolio and a regression approach. We then examine how fund size and investment style interact with the observed relation. Finally, we analyze the trades of mutual funds to further explore the relation between industry concentration and fund performance. 


\section{A. Portfolio Evidence}

To gauge the relative performance of funds with different concentration levels, we sort all mutual funds into ten portfolios according to their Industry Concentration Index at the end of each quarter. For each decile portfolio, we compute the equally weighted average return for each quarter. For this estimation, we use the performance information from all funds, including funds with short return histories, thus mitigating a potential selection bias.

\section{A.1. Factor-Based Performance Measures}

Table II summarizes the results of the unconditional and conditional four-factor models, as in equations (2) and (3). We examine the factor-adjusted returns before and after subtracting expenses. Looking at the returns before expenses enables us to better evaluate the investment ability of mutual fund managers, since managers with better skills may charge higher expenses to extract rents, as discussed in Berk and Green (2004). On the other hand, the returns after expenses are important for mutual fund investors.

\section{[Insert Table II around here]}

The unconditional abnormal returns before expenses are summarized in the first column. The results indicate that the most diversified fund portfolio generates an abnormal return of $0.09 \%$ per quarter, while the most concentrated fund portfolio generates an abnormal return of $0.53 \%$ per quarter. The abnormal returns of the five most concentrated portfolios are all significantly positive at the $10 \%$ level. In contrast, the 
abnormal returns of the five most diversified portfolios are all not significantly different from 0 . The difference in the quarterly abnormal returns between the five most and the five least concentrated deciles equals 0.30 percentage points per quarter, which is statistically significant at the 5\% level. The magnitude of the performance difference increases further if we compare the top and the bottom quintiles or deciles. The Spearman rank correlation between fund concentration and performance equals 0.87 and is significant at the $1 \%$ level. Hence, the evidence indicates that concentrated funds perform better than diversified funds before deducting expenses.

The second column summarizes the abnormal performance using the conditional four-factor model. In general, the results of the conditional model are stronger and statistically more significant than the results using the unconditional model. Thus, the performance difference between the concentrated and the diversified funds are not driven by their responses to macro-economic conditions.

The ranking of the concentration deciles for the abnormal returns after expenses is very similar to the one before expenses. The most concentrated fund portfolios tend to have positive abnormal net returns, while the least concentrated portfolios tend to have negative abnormal net returns. The difference in the performance between concentrated and diversified funds declines slightly if we study after-expense returns, because highly concentrated funds charge higher expenses than diversified funds. In particular, the average quarterly expenses range from $0.38 \%$ for the most concentrated funds to $0.26 \%$ for the most diversified funds. The after-expense abnormal return of the five most concentrated deciles exceeds that of the five least concentrated deciles by 0.24 percentage 
points per quarter. A trading strategy of going long in the most concentrated portfolios and going short in the most diversified portfolios would have generated these riskadjusted returns. Therefore, concentrated funds appear to outperform diversified funds even after taking into account fund expense ratios.

To examine the risk and style characteristics of the decile portfolios, we report the factor loadings of an unconditional four-factor model using before-expense returns in the last four columns of Table II. In our sample, the coefficient on the market factor does not differ much among the ten portfolios. We observe that diversified funds tend to hold large and value companies, whereas concentrated funds tend to hold small and growth companies. Concentrated funds exhibit more momentum in their returns than diversified funds. Therefore, we rely on the four-factor Carhart model and the DGTW model to control for momentum.

\section{A.2. Holding-Based Performance Measures}

DGTW (1997) propose an alternative method to estimate the performance of mutual funds based on the portfolio holdings (equations 4 to 6). This method sheds light on the causes of the performance of mutual funds. Specifically, the DGTW performance measures detect whether mutual fund managers successfully select stocks that outperform a portfolio of stocks with the same characteristics and whether fund managers successfully time these characteristics. 
Table III summarizes the three performance measures for the concentration decile portfolios. Overall, the average performance during our sample period, 1984 to 1999 , is similar to that reported by DGTW (1997) using data from 1975 to $1994 .^{8}$

[Insert Table III around here]

Concentrated mutual funds tend to have higher selectivity measures $C S$ and higher timing measures $C T$ than diversified mutual funds. The difference in the $C S$ measures between the five most and the five least concentrated deciles equals 0.20 percentage points per quarter, while the respective difference in the $C T$ measures equals 0.06 percentage points per quarter. The $C S$ and the $C T$ measures of the decile portfolios increase almost monotonically with the Industry Concentration Index, which results in statistically significant Spearman rank correlations. Consistent with our earlier results, concentrated funds exhibit better stock picking and style timing abilities than diversified funds.

\section{B. Multivariate Regression Evidence}

In this section, we further extend our analysis using multivariate regressions. This approach differs from the portfolio approach in three major respects. First, the decile portfolio analysis does not control for mutual fund characteristics that are related to fund performance. For example, well-diversified mutual funds are, on average, larger than concentrated funds. It might be that smaller funds perform better than larger funds, and

\footnotetext{
${ }^{8}$ DGTW compute an annualized average CS measure of $0.77 \%$, while our results show an annualized average CS measure of $0.96 \%$. Their results are statistically significant at the $5 \%$ level, while our results are significant at the $10 \%$ level. The CT measure is neither statistically significant in their paper nor in our paper.
} 
that the concentration level matters only because it is correlated with size. A multivariate regression framework simultaneously controls for these different factors. Second, the portfolio approach aggregates mutual funds of similar concentration levels into different groups. Here, we take advantage of the rich panel of individual mutual funds. Third, in the previous section we assume constant factor loadings across time. To take into account possible time variations in the factor loadings of individual funds, the regressions use past data to estimate the four-factor model and determine the abnormal returns during a subsequent period. In the regression analyses, we examine the concentration-performance relation using the unconditional and conditional four-factor as well as the holding-based performance measures.

\section{B.1. Factor-Based Performance Measures}

We use three years of past monthly returns to estimate the coefficients of the unconditional and conditional factor models. Subsequently, we subtract the expected return from the realized fund return to determine the abnormal return of a fund in each quarter. $^{9}$

Next, we regress the abnormal return of each mutual fund in each quarter on the Industry Concentration Index and on other fund characteristics. We lag all explanatory variables by one quarter, except for expenses and turnover, which are lagged by one year due to data availability. Using the lagged explanatory variables mitigates potential endogeneity problems. We take the natural logarithms of the age and the size variables, 
because both variables are skewed to the right. Wermers (2003) shows that flows by mutual fund investors can have an impact on asset prices. To control for the effect of lagged inflows, we include the lagged-quarter flows into each mutual fund as an additional explanatory variable. ${ }^{10}$ Each regression additionally includes time fixed effects.

We estimate the regressions with panel-corrected standard errors (PCSE). The PCSE specification adjusts for the contemporaneous correlation and heteroskedasticity among fund returns as well as for the autocorrelation within each fund's returns (Beck and Katz, 1995). We analyze the unbalanced panel, since most mutual funds do not exist over the whole sample period. Table IV summarizes the regression results.

\section{[Insert Table IV around here]}

The first column shows the coefficients from the panel regression using the abnormal return based on the unconditional four-factor model as the dependent variable. The sign and magnitude of the coefficient on the Industry Concentration Index are consistent with our previous analysis using the concentration decile portfolios. Specifically, an increase in the Industry Concentration Index by 5 percentage points (corresponding approximately to one-standard-deviation of the Industry Concentration Index) increases the quarterly abnormal return of a mutual fund by 13 basis points (= $2.57 * 5=12.85$ ), or by approximately 0.52 percentage points on an annual basis. This effect is economically and statistically significant. On average, expenses have a

\footnotetext{
${ }^{9}$ One limitation of this approach is that we have to exclude young mutual funds that do not have a sufficiently long return history.

${ }^{10}$ We calculate quarter flows following Gruber (1996) and Zheng (1999).
} 
statistically significant negative effect on the abnormal return of the mutual fund. Fund age is negatively related to fund performance, and lagged cash flow is positively related to fund performance.

In the second column of Table IV, we use the conditional abnormal return as the dependent variable. The coefficient on the Industry Concentration Index remains similar and is statistically significant at the $1 \%$ level. This result indicates that the superior performance of concentrated funds cannot be attributed to their greater responsiveness to macro-economic conditions.

\section{B.2. Holding-Based Performance Measures}

Columns three and four of Table IV summarize estimation results using holdingbased performance measures, $\mathrm{CS}$ or $\mathrm{CT}$, as the dependent variable, respectively. The results show that mutual funds with a high Industry Concentration Index have better stock selection and better style timing abilities. Specifically, a one-standard-deviation increase in the Industry Concentration Index increases the quarterly $C S$ measure by 14.7 basis points, and the $C T$ measure by 4.7 basis points. Compared to the previous portfolio results, taking advantage of the rich panel structure of our data set and controlling for other mutual fund characteristics result in a significant relation between mutual fund concentration and characteristic-based performance measures.

Overall, the regression results confirm our earlier evidence using decile portfolios that concentrated funds outperform diversified funds by an economically significant margin during our sample period. 


\section{B.3. Industry-Adjusted Abnormal Performance}

One explanation for the superior performance of concentrated funds is that they select industries with high returns. We test this hypothesis using the previously defined $I S$ and $I T$ measures (equations 7 and 8). The measure $I S$ evaluates the stock-picking ability of a fund within industries, while $I T$ captures the ability of the fund to time industries. The first two columns of Table $\mathrm{V}$ summarize the results of adjusting the portfolio returns for industry, risk, and style. A one-standard-deviation increase in the Industry Concentration Index increases the quarterly $I S$ measure by 9.5 basis points. Likewise, a one-standard-deviation increase in the Industry Concentration Index increases the quarterly $I T$ measure by 7.3 basis points. Both effects are significant at the $1 \%$ level.

$$
\text { [Insert Table V around here] }
$$

These results indicate that concentrated funds outperform diversified funds even after adjusting for the industry performance. Concentrated funds appear to have the ability to select better performing stocks within industries and select better performing industries.

\section{B.4. Appraisal Ratio}

As a portfolio deviates from the market portfolio, it will be exposed to idiosyncratic risk. To take into account the different amount of unique risk across our sample of funds, we use as a performance measure a modified appraisal ratio of Treynor and Black (1973). The appraisal ratio is calculated by dividing the abnormal return by the 
standard deviation of the residuals from a four-factor model. Brown, Goetzmann, and Ross (1995) show that survivorship bias is positively related to fund return variance. Thus, the higher the return volatility, the greater the difference between the ex-post observed mean and the ex-ante expected return. Using the alpha scaled by the idiosyncratic risk as our performance measure mitigates such survivorship problems.

The regression results using the appraisal ratio are presented in the third column of Table V. Consistent with our earlier findings, we observe a positive relation between portfolio concentration and fund performance, which is statistically significant at the $1 \%$ level. The coefficients on the other variables are similar to those using the alternative performance measures. Thus, the empirical results suggest the superior performance of concentrated funds is not driven by the amount of idiosyncratic risk, which is related to survival conditions.

\section{B.5. Sub-Period Performance}

We examine the relation between portfolio concentration and fund performance for two sample periods: 1987 to 1993 and 1994 to 1999. There are significant differences in fund characteristics for the two time periods. For example, many new funds entered the market and the average TNA per fund increased substantially during the latter period. The two periods differ also in the overall stock market performance. The average quarterly market return equals $3.4 \%$ in the first sub-sample and $5.3 \%$ in the second subsample. Thus, it is possible that the concentration-performance relation may differ across the two sub-periods. The results of this analysis, presented in Table VI, suggest that a 
similar positive relation between portfolio concentration and fund performance exists in both sample periods.

$$
\text { [Insert Table VI around here] }
$$

\section{Size Portfolios}

To further analyze whether the effect of the Industry Concentration Index depends on the size of the mutual funds, we segregate the mutual funds into different size portfolios and compare the performance of concentrated and diversified funds within these size portfolios.

The distribution of the assets under management by mutual funds is highly skewed to the right. For example, the median mutual fund in our sample has a TNA of \$104 million, while the largest mutual fund (Fidelity Magellan) reached a TNA of $\$ 97,594$ million in 1999. Diseconomies of scale in money management, as discussed by Berk and Green (2004), make it difficult for very large funds to outperform passive benchmarks even if fund managers are skilled.

To gauge the impact of fund size on the concentration-performance relation, we first sort funds into size quintiles based on the TNAs at the end of the previous quarter. Subsequently, we sort the mutual funds within each size quintile into two equally-sized groups according to their Industry Concentration Index. Mutual funds in the first quintile manage on average $\$ 10.19$ million, while funds in the fifth quintile manage on average $\$ 2,604$ million. 
Our findings, reported in Table VII, confirm the results in Chen, Hong, Huang, and Kubik (2002) that small mutual funds outperform large funds. Specifically, mutual funds in the small size quintile have an abnormal return before expenses of $0.48 \%$ per quarter using the unconditional four-factor model, while funds in the large size quintile have an abnormal return of $0.16 \%$ per quarter. This difference in the abnormal performance is statistically significantly different from zero at the $5 \%$ level.

[Insert Table VII around here]

Table VII focuses primarily on the effects of the Industry Concentration Index on abnormal performance within the size quintiles. We observe a positive performance difference between the high and low concentration funds in all size quintiles using the various performance measures. The concentration effect does not differ significantly between the different size quintiles. This finding indicates that our results are not primarily driven by the smallest mutual funds.

\section{Style Portfolios}

Funds frequently concentrate their holdings in specific investment styles, for example, value vs. growth or small vs. large capitalization stocks. In this section, we investigate to what extent our concentration results are related to funds' investment styles. We sort our sample of mutual funds into four investment styles based on the characteristics of their stock holdings.

Each stock traded on the major U.S. exchanges is grouped into respective quintiles according to its market value and its book-to-market ratio. Subsequently, using 
the quintile information, we compute the value-weighted size score and value score for each mutual fund in each period. For example, a mutual fund that invests only in stocks in the smallest size quintile would have a size score of 1 , while a mutual fund that invests only in the largest size quintile would have a size score of 5. Next, we group all mutual funds according to their size scores and value scores into four portfolios. The smallgrowth portfolio includes mutual funds with below median size scores and below median value scores. Similarly, we define the large-growth, small-value, and large-value portfolios. Finally, we subdivide each of these four portfolios according to their Industry Concentration Index. As a result, we obtain eight portfolios of mutual funds according to their style and concentration characteristics.

Table VIII summarizes the different performance measures of these portfolios of mutual funds. The first two columns report the four-factor abnormal returns before subtracting expenses; the remaining columns report the holding-based DGTW performance measures. Consistent with the findings in DGTW (1997) and Chen, Jegadeesh, and Wermers (2000), we observe that mutual funds investing primarily in small or growth stocks outperform other mutual funds with respect to all performance measures. On the other hand, mutual funds specializing in large-value stocks tend to perform the worst according to all measures. Specifically, mutual funds focusing on small-growth stocks outperform mutual funds specializing in large-value stocks by $0.39 \%$ per quarter, using the unconditional four-factor model. This performance difference is statistically significant at the $10 \%$ level. 


\section{[Insert Table VIII around here]}

Consistent with our earlier findings, mutual funds with a higher industry concentration tend to generate higher abnormal returns before expenses within style categories, unless they specialize in large-value stocks. The least concentrated $50 \%$ of small-growth mutual funds have an abnormal return before expenses of $0.18 \%$ per quarter, while the most concentrated $50 \%$ have an abnormal return of $0.59 \%$ per quarter using the unconditional four-factor model. On the other hand, the least concentrated $50 \%$ of large-value mutual funds have an abnormal return before expenses of $0.06 \%$ per quarter, while the most concentrated $50 \%$ have an abnormal return of $-0.08 \%$ per quarter. The effect of the Industry Concentration Index on the abnormal returns and the statistical significance of the return differences strengthen if we compute conditional instead of unconditional abnormal returns. The results using the holding-based performance measures are also consistent with the results using the abnormal four-factor performance.

\section{E. Trade Portfolios}

To further examine whether concentrated funds have informational advantages, we study the performance of mutual fund trades. Specifically, for each fund, we compute the average quarterly returns of the stocks purchased and sold during the previous six months, as described in Section III-E. In our test, we sort the mutual funds according to their Industry Concentration Index and group them into ten portfolios, as in Tables II and III. 
Table IX summarizes the two performance measures for the portfolios based on stock trades by mutual funds in different concentration deciles. The stocks purchased tend to perform significantly better than the stocks sold. Overall, the stocks purchased have a raw return that exceeds the return of the stocks sold by $1.35 \%$ per quarter. The difference between the buy and the sell portfolio tends to increase with the Industry Concentration Index. The return difference equals $0.95 \%$ for the most diversified decile and $2.11 \%$ for the most concentrated decile. The difference in the differences is both statistically and economically highly significant. The superior performance of the trades of the concentrated funds is due to higher returns of the stocks purchased and lower returns of the stocks sold.

[Insert Table IX around here]

The last three columns of Table IX summarize the return differences for the characteristic-adjusted $C S$ measure. These results confirm the earlier findings using the raw returns that the trades of concentrated funds create significantly more value than the trades of diversified funds.

\section{Conclusions}

The value of active fund management has been a long-standing debate among researchers and practitioners. Mutual fund managers may deviate from the passive market portfolio by concentrating their holdings in specific industries. We investigate whether mutual fund managers hold concentrated portfolios because they have investment skills that are linked to specific industries. 
Using U.S. mutual fund data from 1984 to 1999 , we find that mutual funds differ substantially in their industry concentration, and that concentrated funds tend to follow distinct investment styles. In particular, managers of more concentrated funds overweigh growth and small stocks, whereas managers of more diversified funds hold portfolios that closely resemble the total market portfolio.

We find that funds with concentrated portfolios perform better than funds with diversified portfolios. This finding is robust to various risk-adjusted performance measures, including the four-factor model of Carhart (1997), the conditional factor model of Ferson and Schadt (1996), and the holding-based performance measures of Daniel, Grinblatt, Titman, and Wermers (1997). Analyzing the buy and sell decisions of mutual funds, we find evidence that the trades of concentrated portfolios add more value than the trades of diversified portfolios.

In summary, this paper finds that investment ability is more evident among managers who hold portfolios concentrated in a few industries. The evidence lends support to the value of active fund management. 


\section{APPENDIX}

\section{A. Matching of the CRSP and the CDA Data Sets}

To analyze the relation between industry concentration of mutual funds and their style characteristics, one of our main tasks includes the matching of the CDA mutual fund holdings database and the CRSP mutual fund database. We match funds in the CRSP database to the CDA holdings database. Specifically, given that both data sets have different identifying numbers, we need to use different characteristics to perform the merge. A natural common characteristic used as a merging variable is the name of the fund. The matching procedure is done manually and very often, to avoid any spurious matches, supplemented by additional information from the Web sites of particular funds. In cases where matching by name is not conclusive, we support our matching with additional information about the TNA and the investment objective of the fund.

At the outset, our matched data set includes 4,253 different funds identified both in the CRSP and the CDA databases, which existed at any time between January 1984 and December $1999 .^{11}$ For this sample, we apply another filter, in which we exclude all bond, balanced, money market, index, international, and sector funds. ${ }^{12} \mathrm{We}$ also eliminate fund observations where the TNA of a fund in the previous quarter is less than \$1 million or where fewer than 11 stock holdings are identified. In summary, our final sample includes 1,771 distinct equity funds with complete characteristics of returns, total

\footnotetext{
${ }^{11}$ For funds with multiple share classes, we include the dominant class of shares in CRSP.

${ }^{12}$ We exclude funds that do not predominantly hold U.S. equities.
} 
net assets, age, expenses, loads, turnover, portfolio holdings, style objective, and full name in at least one quarter between 1984 and 1999.

\section{B. Industry Composition}

Kenneth French lists on his Web page the SIC codes for a 48-industry classification (http://mba.tuck.dartmouth.edu/pages/faculty/ken.french/Data_Library) used in Fama and French (1997). Our analysis aggregates these 48 industries into 10 main industry groups as described in Table AI.

[Insert Table AI around here] 


\section{REFERENCES}

Baks, Klaas P., Andrew Metrick, and Jessica Wachter, 2001, Should investors avoid all actively managed mutual funds? A study in Bayesian performance evaluation, Journal of Finance 56, 45-86.

Beck, Nathaniel, and Jonathan N. Katz, 1995, What to do (and not to do) with time-series cross-section data, American Political Science Review 89(3), 634-647.

Berk, Jonathan, and Richard C. Green, 2004, Mutual fund flows and performance in rational markets, Journal of Political Economy, forthcoming.

Brown, Stephen J., and William N. Goetzmann, 1995, Performance persistence, Journal of Finance 50, 679-698.

Brown, Stephen J., William N. Goetzmann, and Stephen Ross, 1995, Survival, Journal of Finance 50, 853-873.

Carhart, Mark M., 1997, On persistence in mutual fund performance, Journal of Finance 52, 57-82.

Carhart, Mark M., Jennifer N. Carpenter, Anthony W. Lynch, and David K. Musto, 2002, Mutual fund survivorship, Review of Financial Studies, 15, 1439-1463.

Chevalier, Judith, and Glenn Ellison, 1997, Risk taking by mutual funds as a response to incentives, Journal of Political Economy 105, 1167-1200. 
Chen, Hsiu-Lang, Narasimhan Jegadeesh, and Russ Wermers, 2000, An examination of the stockholdings and trades of fund managers, Journal of Financial and Quantitative Analysis 35, 343-368.

Chen, Joseph, Harrison Hong, Ming Huang, and Jeffrey Kubik, 2002, Does fund size erode performance? Liquidity, organizational diseconomies and active money management, Working paper, University of Southern California.

Cohen, Randolph, Joshua D. Coval, and Luboš Pástor, 2004, Judging fund managers by the company that they keep, Journal of Finance, forthcoming.

Coval, Joshua D., and Tobias J. Moskowitz, 1999, Home bias at home: Local equity preference in domestic portfolios, Journal of Finance 54, 2045-2074.

Coval, Joshua D., and Tobias J. Moskowitz, 2001, The Geography of Investment: Informed Trading and Asset Prices, Journal of Political Economy 109 (4), 811-841.

Daniel, Kent, Mark Grinblatt, Sheridan Titman, and Russ Wermers, 1997, Measuring mutual fund performance with characteristic-based benchmarks, Journal of Finance 52, 1035-1058.

Del Guercio, Diane, and Paula A. Tkac, 2002, The determinants of the flow of funds of managed portfolios: Mutual funds versus pension funds, Journal of Financial and Quantitative Analysis 37, 523-557. 
Elton, Edwin J., Martin J. Gruber, Sanjiv Das, and Matthew Hlavka, 1993, Efficiency with costly information: A reinterpretation of evidence for managed portfolios, Review of Financial Studies 6, 1-22.

Fama, Eugene F., and Kenneth R. French, 1993, Common risk factors in the return on bonds and stocks, Journal of Financial Economics 33, 3-53.

Fama, Eugene F., and Kenneth R. French, 1997, Industry costs of equity, Journal of Financial Economics 43, 153-193.

Ferson, Wayne, and Rudi Schadt, 1996, Measuring fund strategy and performance in changing economic conditions, Journal of Finance 51, 425-462.

Frank, Mary M., James M. Poterba, Douglas A. Shackelford, and John B. Shoven, 2004, Copycat funds: Information disclosure regulation and the returns to active management in the mutual fund industry, Journal of Law and Economics, forthcoming.

Goetzmann, William N., and Nadev Peles, 1997, Cognitive dissonance and mutual fund investors, Journal of Financial Research 20, 145-158.

Grinblatt, Mark, and Sheridan Titman, 1989, Mutual fund performance: An analysis of quarterly portfolio holdings, Journal of Business 62, 393-416.

Grinblatt, Mark, and Sheridan Titman, 1993, Performance measurement without benchmarks: An examination of mutual fund returns, Journal of Business 66, 47-68. 
Grinblatt, Mark, Sheridan Titman, and Russ Wermers, 1995, Momentum investment strategies, portfolio performance, and herding: A study of mutual fund behavior, American Economic Review 85, 1088-1105.

Gruber, Martin J., 1996, Another puzzle: The growth in actively managed mutual funds, Journal of Finance 51, 783-810.

Hendricks, Darryll, Jayendu Patel, and Richard Zeckhauser, 1993, Hot hands in mutual funds: The persistence of performance 1974-1988, Journal of Finance 48, 93130.

Ippolito, Richard A., 1992, Consumer reaction to measures of poor quality: Evidence from the mutual fund industry, Journal of Law and Economics 35, 45-70.

Jegadeesh, Narasimhan, and Sheridan Titman, 1993, Returns to buying winners and selling losers: Implication for stock market efficiency, Journal of Finance 48, 65-91.

Jensen, Michael C., 1968, The performance of mutual funds in the period 19451964, Journal of Finance 23, 389-416.

Kosowski, Robert, Allan Timmermann, Hal White, and Russ Wermers, 2001, Can mutual fund "stars" really pick stocks? New evidence from a bootstrap analysis, Working paper, INSEAD.

Kothari, S.P., and Jerold B. Warner, 2001, Evaluating mutual fund performance, Journal of Finance 56, 1985-2010. 
Lynch, Anthony W., Jessica Wachter, and Walter Boudry, 2004, Does mutual fund performance vary over the business cycle? Working paper, New York University.

Malkiel, Burton G., 1995, Returns from investing in equity mutual funds 19711991, Journal of Finance 50, 549-572.

Moskowitz, Tobias J., and Mark Grinblatt, 1999, Do industries explain momentum? Journal of Finance 54, 1249-1290.

Nanda, Vikram, Zhi Wang, and Lu Zheng, 2004, Family values and the star phenomenon, Review of Financial Studies 17 (3), 667-698.

Sirri, Erik, and Peter Tufano, 1998, Costly search and mutual fund flows, Journal of Finance 53, 1589-1622.

Treynor, Jack L., and Fisher Black, 1973, How to use security analysis to improve portfolio selection, Journal of Business 46, 66-86.

Wermers, Russ, 2000, Mutual fund performance: An empirical decomposition into stock-picking talent, style, transaction costs, and expenses, Journal of Finance 55, $1655-1703$.

Wermers, Russ, 2003, Is money really "smart"? New evidence on the relation between mutual fund flows, manager behavior, and performance persistence, Working paper, University of Maryland. 
Zheng, Lu, 1999, Is money smart? A study of mutual fund investors' fund selection ability, Journal of Finance 54, 901-933. 


\section{Table I}

\section{Summary Statistics}

Panel A presents the summary statistics of the actively managed equity mutual funds included in the paper. Panel B reports the contemporaneous correlations between the main variables used in the paper. The Industry Concentration Index is defined as $I C I=\sum\left(w_{j}-\bar{w}_{j}\right)^{2}$, where $w_{j}$ is the weight of the mutual fund holdings in industry $j$ and $\bar{w}_{j}$ is the weight of the market in industry $j$.

Panel A: Fund Characteristics

\begin{tabular}{lcccc}
\hline & Mean & Median & Minimum & Maximum \\
\hline Total Number of Funds & 1,771 & & & \\
Number of Stocks Held by Fund & 97.12 & 65 & 11 & 3,439 \\
TNA (Total Net Assets) (in Millions) & 623.44 & 107.18 & 1.001 & 97,594 \\
Age (in Years) & 14.58 & 8 & 1 & 77 \\
Expenses (in \%) & 1.26 & 1.17 & 0.01 & 14.54 \\
Turnover (in \%) & 88.28 & 64.0 & 0.04 & 4263 \\
Total Load (in \%) & 2.55 & 0 & 0 & 8.98 \\
Quarterly Raw Return (in \%) & 4.44 & 4.29 & -49.32 & 130.62 \\
Industry Concentration Index (in \%) & 5.98 & 4.36 & 0.01 & 83.42 \\
\hline
\end{tabular}

Panel B: Correlation Structure

\begin{tabular}{lcccccc}
\hline Variables & $\begin{array}{c}\text { Industry } \\
\text { Concentration } \\
\text { Index }\end{array}$ & Expenses & Turnover & Age & TNA & Loads \\
\hline $\begin{array}{l}\text { Concentration } \\
\text { Index }\end{array}$ & 1.00 & & & & & \\
Expenses & $0.21^{* * *}$ & 1.00 & & & & \\
Turnover & $0.15^{* * *}$ & $0.14^{* * *}$ & 1.00 & & & \\
Age & $-0.08^{* * *}$ & $-0.19^{* * *}$ & $-0.07^{* * *}$ & 1.00 & & \\
TNA & $-0.06^{* * *}$ & $-0.15^{* * *}$ & $-0.03^{* * *}$ & $0.20^{* * *}$ & 1.00 & \\
Loads & $-0.05^{* * *}$ & $0.01^{* * *}$ & $-0.04^{* * *}$ & $0.17^{* * *}$ & $0.02^{* * *}$ & 1.00 \\
\hline
\end{tabular}

$* * * 1 \%$ significance; $* * 5 \%$ significance; $* 10 \%$ significance 


\section{Table II \\ Decile Portfolios}

This table summarizes abnormal returns and the factor loadings using the Carhart (1997) four-factor model for different portfolios of mutual funds for the period of 1984 to 1999. The first and third columns show the unconditional abnormal returns before and after expenses. The second and fourth columns show the conditional abnormal returns according to Ferson and Schadt (1996), using the lagged level of the one-month Treasury bill yield, the lagged dividend yield of the S\&P 500 Index, the lagged measure of the slope of the term structure, and the lagged quality spread in the bond market. The last four columns summarize the factor loadings for the unconditional model using returns before expenses. We divide the sample into deciles based on the lagged Industry Concentration Index $I C I=\sum\left(w_{j}-\bar{w}_{j}\right)^{2}$, where $w_{j}$ is the weight of the mutual fund holdings in industry $j$ and $\bar{w}_{j}$ is the weight of the market in industry $j$. The returns are expressed at a quarterly frequency and the portfolios are rebalanced quarterly. The standard errors of the regressions are given in parentheses. The table includes the differences in the abnormal returns along with their standard errors before and after expenses between the top and the bottom deciles, the top and the bottom quintiles, and the top and the bottom halves of the mutual funds. Spearman rank correlations have been included together with their respective $p$-values.

\begin{tabular}{|c|c|c|c|c|c|c|c|c|}
\hline & \multicolumn{4}{|c|}{$\begin{array}{l}\text { Abnormal Return } \\
\text { (in \% per quarter) }\end{array}$} & \multicolumn{4}{|c|}{ Factor Loadings } \\
\hline & \multicolumn{2}{|c|}{ Before Expenses } & \multicolumn{2}{|c|}{ After Expenses } & \multirow{2}{*}{\multicolumn{4}{|c|}{$\begin{array}{l}\text { Before Expenses } \\
\text { Unconditional Model }\end{array}$}} \\
\hline & Uncon- & Con- & Uncon- & Con- & & & & \\
\hline & ditional & ditional & ditional & ditional & Market & Size & Value & Momentum \\
\hline \multirow[t]{2}{*}{ All Funds } & $0.24 * * *$ & $0.21 * *$ & -0.07 & -0.11 & $0.96^{* * *}$ & $0.28 * * *$ & $-0.09 * * *$ & $0.03 * *$ \\
\hline & $(0.09)$ & $(0.09)$ & $(0.09)$ & $(0.09)$ & $(0.01)$ & $(0.02)$ & $(0.02)$ & $(0.01)$ \\
\hline 1 & 0.09 & 0.01 & $-0.17^{*}$ & $-0.25 * *$ & $0.97^{* * *}$ & $-0.07 * * *$ & 0.01 & 0.00 \\
\hline Diversified & $(0.10)$ & $(0.10)$ & $(0.10)$ & $(0.10)$ & $(0.01)$ & $(0.02)$ & $(0.02)$ & $(0.02)$ \\
\hline \multirow[t]{2}{*}{2} & 0.08 & 0.03 & $-0.19 *$ & $-0.24 * *$ & $0.96^{* * *}$ & 0.03 & 0.01 & -0.01 \\
\hline & $(0.11)$ & $(0.12)$ & $(0.11)$ & $(0.12)$ & $(0.01)$ & $(0.02)$ & $(0.02)$ & $(0.02)$ \\
\hline \multirow[t]{2}{*}{3} & 0.10 & 0.07 & -0.18 & $-0.22 *$ & $0.96^{* * *}$ & $0.13 * * *$ & 0.01 & 0.00 \\
\hline & $(0.11)$ & $(0.12)$ & $(0.11)$ & $(0.12)$ & $(0.01)$ & $(0.02)$ & $(0.02)$ & $(0.02)$ \\
\hline \multirow[t]{2}{*}{4} & 0.08 & -0.03 & -0.21 & $-0.32 *$ & $0.97 * * *$ & $0.21 * * *$ & 0.02 & 0.02 \\
\hline & $(0.17)$ & $(0.17)$ & $(0.17)$ & $(0.17)$ & $(0.02)$ & $(0.03)$ & $(0.03)$ & $(0.03)$ \\
\hline \multirow[t]{2}{*}{5} & 0.10 & 0.02 & -0.21 & $-0.30 *$ & $0.97^{* * *}$ & $0.24 * * *$ & -0.00 & -0.01 \\
\hline & $(0.17)$ & $(0.17)$ & $(0.17)$ & $(0.17)$ & $(0.02)$ & $(0.03)$ & $(0.03)$ & $(0.02)$ \\
\hline \multirow[t]{2}{*}{6} & $0.33 *$ & 0.29 & 0.16 & -0.03 & $0.97 * * *$ & $0.31 * * *$ & -0.02 & 0.02 \\
\hline & $(0.18)$ & $(0.19)$ & $(0.18)$ & $(0.19)$ & $(0.02)$ & $(0.03)$ & $(0.03)$ & $(0.03)$ \\
\hline \multirow[t]{2}{*}{7} & $0.44 * *$ & $0.37 *$ & 0.11 & 0.04 & $0.96^{* * *}$ & $0.38 * * *$ & $-0.07 * *$ & 0.03 \\
\hline & $(0.19)$ & $(0.20)$ & $(0.19)$ & $(0.20)$ & $(0.02)$ & $(0.04)$ & $(0.04)$ & $(0.03)$ \\
\hline \multirow[t]{2}{*}{8} & $0.26^{*}$ & $0.30 *$ & -0.08 & -0.04 & $0.97 * * *$ & $0.49 * * *$ & $-0.16 * * *$ & $0.05^{* *}$ \\
\hline & $(0.16)$ & $(0.16)$ & $(0.16)$ & $(0.16)$ & $(0.02)$ & $(0.03)$ & $(0.03)$ & $(0.02)$ \\
\hline \multirow[t]{2}{*}{9} & $0.42 * *$ & $0.41 * *$ & 0.07 & 0.07 & $0.99 * * *$ & $0.49 * * *$ & $-0.25 * * *$ & $0.07 * *$ \\
\hline & $(0.18)$ & $(0.20)$ & $(0.18)$ & $(0.20)$ & $(0.02)$ & $(0.04)$ & $(0.03)$ & $(0.03)$ \\
\hline 10 & $0.53 *$ & $0.59 * *$ & 0.15 & 0.22 & $0.93 * * *$ & $0.64 * * *$ & $-0.47 * * *$ & $0.12 * * *$ \\
\hline Concentrated & $(0.29)$ & $(0.30)$ & $(0.29)$ & $(0.30)$ & $(0.04)$ & $(0.05)$ & $(0.05)$ & $(0.04)$ \\
\hline $2^{\text {nd }}$ Half - & $0.30^{* *}$ & $0.37 * * *$ & $0.24 *$ & $0.32^{* *}$ & -0.00 & $0.35 * * *$ & $-0.20 * * *$ & $0.06^{* * *}$ \\
\hline $1^{\text {st }}$ Half & $(0.14)$ & $(0.14)$ & $(0.14)$ & $(0.14)$ & $(0.02)$ & $(0.03)$ & $(0.03)$ & $(0.02)$ \\
\hline $5^{\text {th }}$ Quintile - & $0.39 * *$ & $0.48^{* *}$ & 0.29 & $0.39 *$ & -0.01 & $0.58 * * *$ & $-0.37 * * *$ & $0.10 * * *$ \\
\hline $1^{\text {st }}$ Quintile & $(0.20)$ & $(0.21)$ & $(0.20)$ & $(0.21)$ & $(0.03)$ & $(0.04)$ & $(0.04)$ & $(0.03)$ \\
\hline $10^{\text {th }}$ Decile - & 0.44 & $0.58 *$ & 0.32 & 0.47 & -0.04 & $0.70 * * *$ & $-0.48 * * *$ & $0.12 * *$ \\
\hline $1^{\text {st }}$ Decile & $(0.30)$ & $(0.32)$ & $(0.30)$ & $(0.32)$ & $(0.04)$ & $(0.06)$ & $(0.06)$ & $(0.05)$ \\
\hline Spearman & $0.87 * * *$ & $0.85^{* * *}$ & $0.71 * *$ & $0.78 * * *$ & -0.04 & $0.99 * * *$ & $-0.92 * * *$ & $0.82 * * *$ \\
\hline Rank Correl. & $(0.00)$ & $(0.00)$ & $(0.02)$ & $(0.01)$ & $(0.91)$ & $(0.00)$ & $(0.00)$ & $(0.00)$ \\
\hline
\end{tabular}

*** 1\% significance; $* * 5 \%$ significance; $* 10 \%$ significance 


\section{Table III \\ Holding-Based Performance}

This table summarizes holding-based performance measures according to DGTW (1997) for different portfolios of mutual funds for the period of 1984 to 1999 . We divide the sample into deciles based on the lagged Industry Concentration Index, which is defined as $I C I=\sum\left(w_{j}-\bar{w}_{j}\right)^{2}$, where $w_{j}$ is the weight of the mutual fund holdings in industry $j$ and $\bar{w}_{j}$ is the weight of the market in industry $j$. The returns are expressed at a quarterly frequency and the portfolios are rebalanced quarterly. The characteristic-based performance measures are denoted by $C S, C T$, and $A S$. The stock selection ability is defined as $C S=$ $\sum w_{j, t-1}\left[R_{j, t}-B R_{t}(j, t-1)\right]$, where $B R_{t}(j, t-1)$ denotes the return of a benchmark portfolio during period $t$ to which stock $j$ was allocated during period $t-1$ according to its size, value, and momentum characteristics. The style-timing ability is defined as $C T=\sum\left[w_{j, t-1} B R_{t}(j, t-1)-w_{j, t-5} B R_{t}(j, t-5)\right]$ and the style-selection ability is defined as $A S=\sum\left[w_{j, t-5} B R_{t}(j, t-5)\right]$. The standard errors of the regressions are given in parentheses. The table includes the differences in the abnormal returns along with their standard errors between the top and the bottom deciles, the top and the bottom quintiles, and the top and the bottom halves of the mutual funds. Spearman rank correlations have been included together with their respective $p$-values.

\begin{tabular}{|c|c|c|c|}
\hline \multirow[t]{2}{*}{ Deciles } & \multicolumn{3}{|c|}{ Holding-Based Performance (in \% per quarter) } \\
\hline & $C S$ & $C T$ & $A S$ \\
\hline \multirow{2}{*}{ All Funds } & $0.24 *$ & 0.08 & $4.26^{* * *}$ \\
\hline & $(0.13)$ & $(0.06)$ & $(1.12)$ \\
\hline \multirow[t]{2}{*}{1 Diversified } & 0.13 & 0.03 & $4.48^{* * *}$ \\
\hline & $(0.12)$ & $(0.08)$ & $(1.03)$ \\
\hline \multirow[t]{2}{*}{2} & 0.14 & 0.04 & $4.36^{* * *}$ \\
\hline & $(0.11)$ & $(0.07)$ & $(1.04)$ \\
\hline \multirow[t]{2}{*}{3} & 0.13 & 0.04 & $4.31 * * *$ \\
\hline & $(0.11)$ & $(0.06)$ & $(1.07)$ \\
\hline \multirow[t]{2}{*}{4} & 0.16 & 0.08 & $4.23 * * *$ \\
\hline & $(0.12)$ & $(0.06)$ & $(1.08)$ \\
\hline \multirow[t]{2}{*}{5} & 0.14 & 0.06 & $4.20 * * *$ \\
\hline & $(0.12)$ & $(0.06)$ & $(1.09)$ \\
\hline \multirow[t]{2}{*}{6} & $0.24 *$ & 0.05 & $4.26^{* * *}$ \\
\hline & $(0.13)$ & $(0.06)$ & $(1.12)$ \\
\hline \multirow[t]{2}{*}{7} & $0.33^{* *}$ & 0.09 & $4.17 * * *$ \\
\hline & $(0.17)$ & $(0.06)$ & $(1.14)$ \\
\hline \multirow[t]{2}{*}{8} & 0.21 & 0.11 & $4.17 * * *$ \\
\hline & $(0.20)$ & $(0.08)$ & $(1.18)$ \\
\hline \multirow[t]{2}{*}{9} & $0.40^{*}$ & $0.15^{*}$ & $4.17 * * *$ \\
\hline & $(0.24)$ & $(0.09)$ & $(1.20)$ \\
\hline \multirow[t]{2}{*}{10 Concentrated } & 0.53 & 0.13 & $4.22 * * *$ \\
\hline & $(0.33)$ & $(0.10)$ & $(1.27)$ \\
\hline \multirow[t]{2}{*}{$2^{\text {nd }}$ Half $-1^{\text {st }}$ Half } & 0.20 & 0.06 & -0.12 \\
\hline & $(0.15)$ & $(0.05)$ & $(0.20)$ \\
\hline \multirow[t]{2}{*}{$5^{\text {th }}$ Quintile $-1^{\text {st }}$ Quintile } & 0.33 & 0.11 & -0.23 \\
\hline & $(0.28)$ & $(0.08)$ & $(0.34)$ \\
\hline \multirow[t]{2}{*}{$10^{\text {th }}$ Decile $-1^{\text {st }}$ Decile } & 0.40 & 0.11 & -0.26 \\
\hline & $(0.34)$ & $(0.11)$ & $(0.41)$ \\
\hline \multirow[t]{2}{*}{ Spearman Rank Correlation } & $0.88 * * *$ & $0.93 * * *$ & $-0.82 * * *$ \\
\hline & $(0.00)$ & $(0.00)$ & $(0.00)$ \\
\hline
\end{tabular}

*** $1 \%$ significance; $* * 5 \%$ significance; $* 10 \%$ significance 


\section{Table IV \\ Regression Evidence}

This table reports the coefficients of the quarterly panel regression of the general form: $P E R F_{i, t}=\beta_{0}+$ $\beta_{1} * I C I_{i, t-1}+\beta_{2} * L T N A_{i, t-1}+\beta_{3} * E X P_{i, t-1}+\beta_{4} * L A G E_{i, t-1}+\beta_{5} * T U_{i, t-1}+\beta_{6} * N M G_{i, t-1}+\varepsilon_{i, t}$. The sample includes actively managed equity mutual funds and spans the period of 1984 to 1999 (including the data used for calculating the abnormal returns). The dependent variable, PERF, measures the quarterly performance using the four-factor model of Carhart (1997) based on 36 months of lagged data, the conditional performance according to Ferson and Schadt (1996), and the holding-based performance measures, $C S$ and $C T$ according to DGTW (1997). The Industry Concentration Index is defined as $I C I=\sum\left(w_{j}-\bar{w}_{j}\right)^{2}$, where $w_{j}$ is the weight of the mutual fund holdings in industry $j$ and $\bar{w}_{j}$ is the weight of the market in industry $j$. We denote the expense ratio by EXP, the turnover ratio by $T U$, the natural logarithm of age by $L A G E$, the natural logarithm of total net assets by $L T N A$, and the new money growth by $N M G$. All regressions include time dummies. Panel-corrected standard errors for panel regressions have been provided in parentheses.

\begin{tabular}{lcccc}
\hline & \multicolumn{2}{c}{$\begin{array}{c}\text { Dependent Variable: Quarterly Performance (in bp) } \\
\text { Four-Factor } \\
\text { Abnormal Return }\end{array}$} & $\begin{array}{c}\text { Holding-Based } \\
\text { Performance }\end{array}$ \\
& Unconditional & Conditional & $C S$ & $C T$ \\
\hline$I C I$ & $2.57^{* * *}$ & $2.82^{* * *}$ & $2.94^{* * *}$ & $0.94^{* * *}$ \\
(in \%) & $(0.62)$ & $(0.77)$ & $(0.56)$ & $(0.23)$ \\
$E X P$ & $-40.16^{* * *}$ & $-46.07^{* * *}$ & -2.15 & 2.61 \\
(in \%) & $(6.84)$ & $(10.26)$ & $(5.70)$ & $(2.48)$ \\
$T U$ & 0.04 & 0.07 & $0.18^{* * *}$ & $0.06^{* * *}$ \\
(in \%) & $(0.05)$ & $(0.06)$ & $(0.04)$ & $(0.02)$ \\
$L A G E$ & $-12.37^{* * *}$ & $-20.10^{* * *}$ & 1.71 & -1.66 \\
& $(3.21)$ & $(4.18)$ & $(2.70)$ & $(1.34)$ \\
$L T N A$ & -1.16 & -1.65 & 2.15 & 0.16 \\
& $(1.64)$ & $(2.09)$ & $(1.53)$ & $(0.74)$ \\
$N M G$ & 0.16 & 0.16 & $0.28^{* *}$ & $0.20^{* * *}$ \\
& $(0.18)$ & $(0.23)$ & $(0.13)$ & $(0.07)$ \\
\hline No. of obs. & 30,645 & 30,645 & 42,659 & 36,325 \\
\hline
\end{tabular}

*** $1 \%$ significance; $* * 5 \%$ significance; $* 10 \%$ significance 


\section{Table V}

\section{Alternative Risk Adjustments}

This table reports the coefficients of the quarterly panel and cross-sectional regression of the general form: $P E R F_{i, t}=\beta_{0}+\beta_{1} * I C I_{i, t-1}+\beta_{2} * L T N A_{i, t-1}+\beta_{3} * E X P_{i, t-1}+\beta_{4} * L A G E_{i, t-1}+\beta_{5} * T U_{i, t-1}+\beta_{6} * N M G_{i, t-1}+\varepsilon_{i, t}$. The sample includes actively managed equity mutual funds and spans the period of 1984 to 1999 (including the data used for calculating the abnormal returns). The dependent variable, PERF, equals the industryadjusted stock selectivity measure (IS), the industry-adjusted timing measure (IT), or the appraisal ratio of Treynor and Black (1973) based on the four-factor model. The Industry Concentration Index is defined as $I C I=\sum\left(w_{j}-\bar{w}_{j}\right)^{2}$, where $w_{j}$ is the weight of the mutual fund holdings in industry $j$ and $\bar{w}_{j}$ is the weight of the market in industry $j$. We denote the expense ratio by $E X P$, the turnover ratio by $T U$, the natural logarithm of age by $L A G E$, the natural logarithm of total net assets by LTNA, and the new money growth by $N M G$. All regressions include time dummies. Panel-corrected standard errors for panel regressions have been provided in parentheses.

\begin{tabular}{lccc}
\hline & $\begin{array}{c}\text { Dependent Variable: Quarterly Performance (in bp) } \\
\text { Industry-Adjusted Abnormal Performance }\end{array}$ & $\begin{array}{c}\text { Appraisal Ratio } \\
\text { Four-factor }\end{array}$ \\
\hline ICI & IS & IT & $0.65^{* * *}$ \\
(in \%) & $1.89^{* * *}$ & $1.46^{* * *}$ & $(0.09)$ \\
$E X P$ & $(0.47)$ & $(0.19)$ & $-6.58^{* * *}$ \\
(in \%) & 7.32 & 3.24 & $(0.95)$ \\
$T U$ & $(5.98)$ & $(2.78)$ & $0.01^{* *}$ \\
(in \%) & $0.10^{* * *}$ & $0.12^{* * *}$ & $(0.01)$ \\
LAGE & $(0.03)$ & $(0.02)$ & $-2.54^{* * *}$ \\
& -1.51 & $-8.72^{* * *}$ & $(0.72)$ \\
LTNA & $(2.32)$ & $(1.15)$ & -0.43 \\
& $9.91 * * *$ & $2.00^{* * *}$ & $(0.35)$ \\
$N M G$ & $(1.38)$ & $(0.62)$ & 0.91 \\
& $0.23^{* *}$ & $0.13^{* *}$ & $(3.49)$ \\
\hline Obs. & $(0.11)$ & $(0.06)$ & 30,645 \\
\hline$* * * 1 \%$ significance; $* *$ 5 significance; $* 10 \%$ significance & 33,025 &
\end{tabular}




\section{Table VI}

\section{Sub-Period Evidence}

This table reports the coefficients of the quarterly panel regression of the general form: $P E R F_{i, t}=\beta_{0}+$ $\beta_{1} * I C I_{i, t-1}+\beta_{2} * L T N A_{i, t-1}+\beta_{3} * E X P_{i, t-1}+\beta_{4} * L A G E_{i, t-1}+\beta_{5} * T U_{i, t-1}+\beta_{6} * N M G_{i, t-1}+\varepsilon_{i, t}$. The sample includes actively managed equity mutual funds and spans the period of 1987 to 1993 (left panel) and 1994 to 1999 (right panel). The dependent variable, $P E R F$, measures the quarterly abnormal performance using the fourfactor model of Carhart (1997) based on 36 months of lagged data. The Industry Concentration Index is defined as $I C I=\sum\left(w_{j}-\bar{w}_{j}\right)^{2}$, where $w_{j}$ is the weight of the mutual fund holdings in industry $j$ and $\bar{w}_{j}$ is the weight of the market in industry $j$. We denote the expense ratio by EXP, the turnover ratio by $T U$, the natural logarithm of age by $L A G E$, the natural logarithm of total net assets by LTNA, and the new money growth by $N M G$. All regressions include time dummies. Panel-corrected standard errors have been provided in parentheses.

\begin{tabular}{|c|c|c|}
\hline & \multicolumn{2}{|c|}{$\begin{array}{l}\text { Dependent Variable: Quarterly Abnormal Returns (in bp) } \\
\text { Four-Factor Model }\end{array}$} \\
\hline & 1987-1993 & 1994-1999 \\
\hline$I C I$ & $2.44^{* * *}$ & $2.85^{* * *}$ \\
\hline (in \%) & $(0.85)$ & $(0.88)$ \\
\hline EXP & $-30.61 * * *$ & $-45.59 * * *$ \\
\hline (in \%) & $(8.03)$ & (11.18) \\
\hline$T U$ & -0.01 & 0.08 \\
\hline (in \%) & $(0.05)$ & $(0.07)$ \\
\hline \multirow[t]{2}{*}{$L A G E$} & $-12.40 * * *$ & $-11.74 * * *$ \\
\hline & $(4.43)$ & $(4.40)$ \\
\hline \multirow[t]{2}{*}{$L T N A$} & $4.39 *$ & -3.44 \\
\hline & (2.61) & $(2.12)$ \\
\hline \multirow[t]{2}{*}{$N M G$} & 0.04 & 0.21 \\
\hline & $(0.32)$ & $(0.23)$ \\
\hline Observations & 10,948 & 19,697 \\
\hline
\end{tabular}




\section{Table VII \\ Mutual Fund Size Portfolios}

Mutual funds are sorted at the beginning of each period into five equally-sized portfolios according to the lagged TNA of the mutual funds. The mutual funds in each of these five portfolios are further divided into two groups according to the lagged Industry Concentration Index. The Industry Concentration Index is defined as $I C I=\sum\left(w_{j}-\bar{w}_{j}\right)^{2}$, where $w_{j}$ is the weight of the mutual fund holdings in industry $j$ and $\bar{w}_{j}$ is the weight of the market in industry $j$. The returns are expressed at a quarterly frequency and the portfolios are rebalanced quarterly. The abnormal returns before expenses using the Carhart (1997) four-factor model are summarized for different portfolios of mutual funds for the period of 1984 to 1999 . The characteristicbased performance measures are denoted by $C S$ and $C T$. The stock selection ability is defined as $C S=$ $\sum w_{j, t-1}\left[R_{j, t}-B R_{t}(j, t-1)\right]$, where $B R_{t}(j, t-1)$ denotes the return of a benchmark portfolio during period $t$ to which stock $j$ was allocated during period $t-1$ according to its size, value, and momentum characteristics. The style-timing ability is defined as $C T=\sum\left[w_{j, t-1} B R_{t}(j, t-1)-w_{j, t-5} B R_{t}(j, t-5)\right]$. The standard errors of the regressions are given in parentheses.

\begin{tabular}{|c|c|c|c|c|c|}
\hline \multirow[b]{2}{*}{ Size Quintiles } & \multirow[b]{2}{*}{$\begin{array}{c}\text { Industry } \\
\text { Concentration }\end{array}$} & \multicolumn{2}{|c|}{$\begin{array}{c}\text { Four Factor } \\
\text { Abnormal Return }\end{array}$} & \multicolumn{2}{|c|}{$\begin{array}{c}\text { Holding-Based Performance } \\
\text { Measures }\end{array}$} \\
\hline & & Unconditional & Conditional & $C S$ & $C T$ \\
\hline Quintile 1 & Low & $\begin{array}{c}0.36^{* *} \\
(0.15)\end{array}$ & $\begin{array}{l}0.28^{*} \\
(0.15)\end{array}$ & $\begin{array}{c}0.19 * \\
(0.11)\end{array}$ & $\begin{array}{c}0.08 \\
(0.07)\end{array}$ \\
\hline & High & $\begin{array}{l}0.60 * * * \\
(0.19)\end{array}$ & $\begin{array}{l}0.56^{* * *} \\
(0.20)\end{array}$ & $\begin{array}{c}0.26 \\
(0.20)\end{array}$ & $\begin{array}{c}0.12 \\
(0.10)\end{array}$ \\
\hline $\begin{array}{l}\text { Mean TNA: } \\
\$ 10.19 \mathrm{M}\end{array}$ & High-Low & $\begin{array}{c}0.24 \\
(0.20)\end{array}$ & $\begin{array}{c}0.28 \\
(0.20)\end{array}$ & $\begin{array}{c}0.07 \\
(0.15)\end{array}$ & $\begin{array}{c}0.04 \\
(0.08)\end{array}$ \\
\hline Quintile 2 & $\begin{array}{l}\text { Low } \\
\text { High }\end{array}$ & $\begin{array}{c}0.08 \\
(0.16) \\
0.38^{* *} \\
(0.15)\end{array}$ & $\begin{array}{l}0.00 \\
(0.17) \\
0.41 * * * \\
(0.15)\end{array}$ & $\begin{array}{c}0.13 \\
(0.11) \\
0.43^{* *} \\
(0.17)\end{array}$ & $\begin{array}{c}0.08 \\
(0.07) \\
0.14^{*} \\
(0.08)\end{array}$ \\
\hline $\begin{array}{l}\text { Mean TNA: } \\
\$ 42.03 \mathrm{M}\end{array}$ & High-Low & $\begin{array}{l}0.30^{* *} \\
(0.15)\end{array}$ & $\begin{array}{l}0.40^{* * *} \\
(0.15)\end{array}$ & $\begin{array}{l}0.30^{* *} \\
(0.15)\end{array}$ & $\begin{array}{c}0.05 \\
(0.06)\end{array}$ \\
\hline Quintile 3 & $\begin{array}{l}\text { Low } \\
\text { High }\end{array}$ & $\begin{array}{c}0.07 \\
(0.14) \\
0.27 \\
(0.19)\end{array}$ & $\begin{array}{c}-0.04 \\
(0.14) \\
0.27 \\
(0.20)\end{array}$ & $\begin{array}{c}0.10 \\
(0.11) \\
0.28 \\
(0.23)\end{array}$ & $\begin{array}{c}0.01 \\
(0.06) \\
0.09 \\
(0.06)\end{array}$ \\
\hline $\begin{array}{l}\text { Mean TNA: } \\
\$ 109.11 \mathrm{M}\end{array}$ & High-Low & $\begin{array}{c}0.20 \\
(0.19)\end{array}$ & $\begin{array}{c}0.31^{*} \\
(0.20)\end{array}$ & $\begin{array}{c}0.18 \\
(0.20)\end{array}$ & $\begin{array}{c}0.07 \\
(0.05)\end{array}$ \\
\hline Quintile 4 & $\begin{array}{l}\text { Low } \\
\text { High }\end{array}$ & $\begin{array}{c}0.02 \\
(0.14) \\
0.34^{*} \\
(0.20)\end{array}$ & $\begin{array}{c}-0.05 \\
(0.10) \\
0.31 \\
(0.21)\end{array}$ & $\begin{array}{c}0.14 \\
(0.11) \\
0.38^{*} \\
(0.20)\end{array}$ & $\begin{array}{c}0.03 \\
(0.08) \\
0.08 \\
(0.07)\end{array}$ \\
\hline $\begin{array}{l}\text { Mean TNA: } \\
\$ 302.37 \mathrm{M}\end{array}$ & High-Low & $\begin{array}{c}0.33^{*} \\
(0.17)\end{array}$ & $\begin{array}{r}0.35^{*} \\
(0.18) \\
\end{array}$ & $\begin{array}{c}0.24 \\
(0.17)\end{array}$ & $\begin{array}{c}0.05 \\
(0.06)\end{array}$ \\
\hline Quintile 5 & $\begin{array}{l}\text { Low } \\
\text { High }\end{array}$ & $\begin{array}{c}0.07 \\
(0.10) \\
0.24 \\
(0.18)\end{array}$ & $\begin{array}{c}0.05 \\
(0.10) \\
0.28 \\
(0.19)\end{array}$ & $\begin{array}{c}0.16 \\
(0.12) \\
0.27 \\
(0.21)\end{array}$ & $\begin{array}{c}0.05 \\
(0.07) \\
0.10 \\
(0.07)\end{array}$ \\
\hline $\begin{array}{l}\text { Mean TNA: } \\
\$ 2,604.22 \mathrm{M}\end{array}$ & High-Low & $\begin{array}{c}0.18 \\
(0.15)\end{array}$ & $\begin{array}{c}0.23 \\
(0.15)\end{array}$ & $\begin{array}{c}0.11 \\
(0.16)\end{array}$ & $\begin{array}{c}0.05 \\
(0.06)\end{array}$ \\
\hline
\end{tabular}

*** $1 \%$ significance; $* * 5 \%$ significance; $* 10 \%$ significance 


\section{Table VIII \\ Style Portfolios}

Mutual funds are sorted at the beginning of each period into four portfolios according to the lagged market values (small vs. large cap) and the lagged book-to-market ratios (growth vs. value) of their holdings. The mutual funds in each of these four portfolios are further divided into two groups according to the lagged Industry Concentration Index. The Industry Concentration Index is defined as $I C I=\sum\left(w_{j}-\bar{w}_{j}\right)^{2}$, where $w_{j}$ is the weight of the mutual fund holdings in industry $j$ and $\bar{w}_{j}$ is the weight of the market in industry $j$. The returns are expressed at a quarterly frequency and the portfolios are rebalanced quarterly. The abnormal returns before expenses using the Carhart (1997) four-factor model are summarized for different portfolios of mutual funds for the period of 1984 to 1999. The characteristic-based performance measures are denoted by $C S$ and $C T$. The stock selection ability is defined as $C S=\sum w_{j, t-1}\left[R_{j, t}-B R_{t}(j, t-1)\right]$, where $B R_{t}(j, t-1)$ denotes the return of a benchmark portfolio during period $t$ to which stock $j$ was allocated during period $t-1$ according to its size, value, and momentum characteristics. The style-timing ability is defined as $C T=\sum\left[w_{j, t-1} B R_{t}(j, t-1)-w_{j, t-5} B R_{t}(j, t-5)\right]$. The standard errors of the regressions are given in parentheses.

\begin{tabular}{|c|c|c|c|c|c|}
\hline \multirow[b]{2}{*}{ Style } & \multirow[b]{2}{*}{$\begin{array}{c}\text { Industry } \\
\text { Concentration }\end{array}$} & \multicolumn{2}{|c|}{$\begin{array}{c}\text { Four-Factor } \\
\text { Abnormal Return }\end{array}$} & \multicolumn{2}{|c|}{$\begin{array}{c}\text { Holding-Based Performance } \\
\text { Measures }\end{array}$} \\
\hline & & Unconditional & Conditional & $C S$ & $C T$ \\
\hline \multirow{6}{*}{$\begin{array}{l}\text { Small } \\
\text { Growth }\end{array}$} & Low & 0.18 & 0.02 & 0.21 & 0.08 \\
\hline & & $(0.21)$ & $(0.20)$ & $(0.16)$ & $(0.08)$ \\
\hline & High & $0.59 * *$ & $0.72 * *$ & $0.62 *$ & 0.19 \\
\hline & & $(0.28)$ & $(0.29)$ & $(0.37)$ & $(0.14)$ \\
\hline & High - Low & 0.40 & $0.70^{* *}$ & 0.41 & 0.11 \\
\hline & & (0.33) & $(0.31)$ & $(0.28)$ & $(0.11)$ \\
\hline \multirow{6}{*}{$\begin{array}{l}\text { Small } \\
\text { Value }\end{array}$} & Low & 0.06 & 0.04 & 0.09 & 0.03 \\
\hline & & $(0.20)$ & $(0.22)$ & $(0.13)$ & $(0.05)$ \\
\hline & High & $0.41 * *$ & $0.41 *$ & 0.14 & 0.08 \\
\hline & & $(0.20)$ & $(0.21)$ & $(0.17)$ & $(0.05)$ \\
\hline & High - Low & $0.35^{* *}$ & $0.37 * *$ & 0.05 & 0.05 \\
\hline & & $(0.15)$ & $(0.15)$ & $(0.11)$ & $(0.04)$ \\
\hline \multirow{6}{*}{$\begin{array}{l}\text { Large } \\
\text { Growth }\end{array}$} & Low & 0.12 & -0.01 & 0.18 & 0.08 \\
\hline & & $(0.14)$ & $(0.13)$ & $(0.13)$ & (0.09) \\
\hline & High & $0.41 * *$ & $0.39 *$ & $0.41 *$ & 0.16 \\
\hline & & $(0.20)$ & $(0.20)$ & $(0.24)$ & $(0.10)$ \\
\hline & High - Low & 0.29 & $0.41 * *$ & 0.24 & 0.07 \\
\hline & & $(0.21)$ & $(0.20)$ & $(0.20)$ & $(0.06)$ \\
\hline Large & Low & 0.06 & 0.01 & 0.09 & 0.01 \\
\hline \multirow{5}{*}{ Value } & & $(0.17)$ & $(0.18)$ & $(0.13)$ & (0.09) \\
\hline & High & -0.08 & -0.14 & 0.06 & -0.02 \\
\hline & & $(0.20)$ & $(0.21)$ & $(0.16)$ & (0.09) \\
\hline & High - Low & -0.14 & -0.15 & -0.03 & -0.03 \\
\hline & & $(0.12)$ & $(0.12)$ & $(0.09)$ & $(0.05)$ \\
\hline
\end{tabular}

$* * * 1 \%$ significance; $* * 5 \%$ significance; $* 10 \%$ significance 


\section{Table IX \\ Trade Portfolios}

This table summarizes the returns of the stocks purchased and sold by different portfolios of mutual funds for the period of 1984 to 1999 . We divide the sample into deciles based on the lagged Industry Concentration Index, which is defined as $I C I=\sum\left(w_{j}-\bar{w}_{j}\right)^{2}$, where $w_{j}$ is the weight of the mutual fund holdings in industry $j$ and $\bar{w}_{j}$ is the weight of the market in industry $j$. The returns are expressed at a quarterly frequency and the portfolios are rebalanced quarterly. For each mutual fund, we compute the raw returns and style-adjusted returns of their stock purchases and sells. The style adjusted return is a measure of stock selection ability and is defined as $C S=\sum w_{j, t-1}\left[R_{j, t}-B R_{t}(j, t-1)\right]$, where $B R_{t}(j, t-1)$ is the return of a benchmark portfolio during period $t$ to which stock $j$ was allocated during period $t-1$ according to its size, value, and momentum characteristics. The table includes the differences in the returns along with their standard errors between the top and the bottom deciles, the top and the bottom quintiles, and the top and the bottom halves of the mutual funds. Spearman rank correlations have been included together with their respective $p$-values.

\begin{tabular}{|c|c|c|c|c|c|c|}
\hline & \multicolumn{3}{|c|}{ Raw Returns } & \multicolumn{3}{|c|}{ CS-Measure } \\
\hline & Buys & Sells & Buys - Sells & Buys & Sells & Buys - Sells \\
\hline All & $5.01 * * *$ & $3.66^{* * *}$ & $1.35^{* * * *}$ & $0.57 * * *$ & $-0.50 *$ & $1.06^{* * *}$ \\
\hline Funds & $(1.31)$ & $(1.22)$ & $(0.42)$ & $(0.22)$ & $(0.29)$ & $(0.31)$ \\
\hline 1 & $4.96^{* * *}$ & $4.01 * * *$ & $0.95^{* *}$ & $0.33^{* *}$ & -0.28 & $0.61 * *$ \\
\hline Diversified & $(1.12)$ & $(1.09)$ & $(0.40)$ & $(0.16)$ & $(0.26)$ & $(0.28)$ \\
\hline \multirow[t]{2}{*}{2} & $4.99 * * *$ & $3.91 * * *$ & $1.08 * * *$ & $0.45^{* * *}$ & -0.26 & $0.71^{* *}$ \\
\hline & $(1.18)$ & $(1.09)$ & $(0.41)$ & $(0.16)$ & $(0.25)$ & $(0.28)$ \\
\hline \multirow[t]{2}{*}{3} & $4.81 * * *$ & $3.68 * * *$ & $1.13 * * *$ & $0.39 * *$ & $-0.52 *$ & $0.92 * * *$ \\
\hline & $(1.19)$ & $(1.16)$ & $(0.37)$ & $(0.16)$ & $(0.27)$ & $(0.28)$ \\
\hline \multirow[t]{2}{*}{4} & $4.93 * * *$ & $3.70 * * *$ & $1.24 * * *$ & $0.50 * * *$ & -0.46 & $0.97 * * *$ \\
\hline & $(1.24)$ & $(1.19)$ & $(0.39)$ & $(0.18)$ & $(0.29)$ & $(0.30)$ \\
\hline \multirow[t]{2}{*}{5} & $4.79 * * *$ & $3.61 * * *$ & $1.17 * * *$ & $0.41 * *$ & -0.52 & $0.93 * * *$ \\
\hline & $(1.26)$ & $(1.20)$ & $(0.41)$ & $(0.19)$ & $(0.31)$ & $(0.35)$ \\
\hline \multirow[t]{2}{*}{6} & $4.86^{* * *}$ & $3.73 * * *$ & $1.13^{* *}$ & $0.45^{* *}$ & -0.43 & $0.88 * * *$ \\
\hline & $(1.30)$ & $(1.24)$ & $(0.36)$ & $(0.20)$ & $(0.32)$ & $(0.29)$ \\
\hline \multirow[t]{2}{*}{7} & $4.91 * * *$ & $3.50 * * *$ & $1.40 * * *$ & $0.54 * *$ & $-0.62 *$ & $1.16^{* * *}$ \\
\hline & $(1.34)$ & $(1.25)$ & $(0.41)$ & $(0.23)$ & $(0.33)$ & $(0.33)$ \\
\hline \multirow[t]{2}{*}{8} & $5.00 * * *$ & $3.36^{* *}$ & $1.64 * * *$ & $0.61 *$ & $-0.72 *$ & $1.32 * * *$ \\
\hline & $(1.46)$ & $(1.32)$ & $(0.50)$ & $(0.34)$ & $(0.38)$ & $(0.39)$ \\
\hline \multirow[t]{2}{*}{9} & $5.20 * * *$ & $3.53 * * *$ & $1.66^{* * *}$ & $0.76^{* *}$ & -0.60 & $1.35 * * *$ \\
\hline & $(1.51)$ & $(1.33)$ & $(0.52)$ & $(0.37)$ & $(0.39)$ & $(0.38)$ \\
\hline 10 & $5.69 * * *$ & $3.57 * *$ & $2.11 * * *$ & $1.28^{* *}$ & -0.55 & $1.82 * * *$ \\
\hline Concentrated & $(1.68)$ & $(1.47)$ & $(0.62)$ & $(0.52)$ & $(0.48)$ & $(0.49)$ \\
\hline $2^{\text {nd }}$ Half - & 0.23 & -0.24 & $0.48 * * *$ & 0.31 & -0.17 & $0.48 * * *$ \\
\hline $1^{\text {st }}$ Half & $(0.37)$ & $(0.30)$ & $(0.17)$ & $(0.22)$ & $(0.23)$ & $(0.17)$ \\
\hline $5^{\text {th }}$ Quintile - & 0.46 & -0.41 & $0.87 * * *$ & 0.62 & -0.31 & $0.93 * * *$ \\
\hline $1^{\text {st }}$ Quintile & $(0.64)$ & $(0.52)$ & $(0.30)$ & $(0.40)$ & $(0.39)$ & $(0.29)$ \\
\hline $10^{\text {th }}$ Decile - & 0.72 & -0.44 & $1.16^{* * *}$ & $0.94^{*}$ & -0.27 & $1.21 * * *$ \\
\hline $1^{\text {st }}$ Decile & $(0.81)$ & $(0.64)$ & $(0.40)$ & $(0.52)$ & $(0.48)$ & $(0.39)$ \\
\hline Spearman Rank & 0.48 & $-0.81 * * *$ & $0.94 * * *$ & $0.89^{* * *}$ & $-0.78 * * *$ & $0.95 * * *$ \\
\hline Correlation & $(0.16)$ & $(0.00)$ & $(0.00)$ & $(0.00)$ & $(0.01)$ & $(0.00)$ \\
\hline
\end{tabular}

*** $1 \%$ significance; $* * 5 \%$ significance; $* 10 \%$ significance 
Table AI

Industry Classification

\begin{tabular}{|c|c|c|c|}
\hline 10-Industry Classification & Weight (in \%) & 48-Industry French Classification & Weight (in \%) \\
\hline \multirow[t]{10}{*}{ 1. Consumer Non-Durables } & 10.08 & 1. Agriculture & 0.10 \\
\hline & & 2. Food Products & 2.48 \\
\hline & & 3. Candy and Soda & 1.93 \\
\hline & & 4. Beer and Liquor & 0.46 \\
\hline & & 5. Tobacco Products & 1.75 \\
\hline & & 7. Entertainment & 0.81 \\
\hline & & 8. Printing and Publishing & 1.57 \\
\hline & & 10. Apparel & 0.48 \\
\hline & & 16. Textiles & 0.20 \\
\hline & & 33. Personal Services & 0.30 \\
\hline \multirow[t]{3}{*}{ 2. Consumer Durables } & 8.74 & 6. Toys & 0.55 \\
\hline & & 9. Consumer Goods & 5.46 \\
\hline & & 23. Automobiles and Trucks & 2.73 \\
\hline \multirow[t]{3}{*}{ 3. Healthcare } & 7.81 & 11. Healthcare & 0.90 \\
\hline & & 12. Medical Equipment & 1.39 \\
\hline & & 13. Pharmaceutical Products & 5.52 \\
\hline \multirow[t]{15}{*}{ 4. Manufacturing } & 15.24 & 14. Chemicals & 2.99 \\
\hline & & 15. Rubber and Plastic Products & 0.25 \\
\hline & & 17. Construction Materials & 1.75 \\
\hline & & 18. Construction & 0.27 \\
\hline & & 19. Steel Works & 1.03 \\
\hline & & 20. Fabricated Products & 0.10 \\
\hline & & 21. Machinery & 1.62 \\
\hline & & 22. Electrical Equipment & 1.23 \\
\hline & & 24. Aircraft & 1.07 \\
\hline & & 25. Shipbuilding and Railroad Equip. & 0.12 \\
\hline & & 26. Defense & 0.27 \\
\hline & & 38. Business Supplies & 1.45 \\
\hline & & 39. Shipping Containers & 0.89 \\
\hline & & 40. Transportation & 1.40 \\
\hline & & 48. Miscellaneous & 0.78 \\
\hline \multirow[t]{4}{*}{ 5. Energy } & 7.78 & 27. Precious Metals & 0.25 \\
\hline & & 28. Mining & 0.32 \\
\hline & & 29. Coal & 0.06 \\
\hline & & 30. Oil & 7.15 \\
\hline 6. Utilities & 6.67 & 31. Utilities & 6.67 \\
\hline 7. Telecom & 5.42 & 32. Communications & 5.42 \\
\hline 8. Business Equipment and & 11.92 & 34. Business Services & 4.09 \\
\hline \multirow[t]{3}{*}{ Services } & & 35. Computers & 4.48 \\
\hline & & 36. Electronic Equipment & 2.47 \\
\hline & & 37. Measuring and Control Equip. & 0.88 \\
\hline \multirow[t]{3}{*}{ 9. Wholesale and Retail } & 8.30 & 41. Wholesale & 1.61 \\
\hline & & 42. Retail & 5.40 \\
\hline & & 43. Restaurants, Hotels, and Motels & 1.28 \\
\hline \multirow[t]{4}{*}{ 10. Finance } & 18.04 & 44. Banking & 3.66 \\
\hline & & 45. Insurance & 3.09 \\
\hline & & 46. Real Estate & 0.23 \\
\hline & & 47. Trading & 11.05 \\
\hline
\end{tabular}

